VISNYK LVIV UNIV.

ерія геогр. 2012. un. 40. . 1. . 149-155 Ser. Geogr. 2012. N 40. . 1. P. 149-155

556.388

\author{
• олошин \\ ьвівський н ціон льний університет імені в н \\ вул. рушевського, 4, м. ьвів, 79005, кр їн
}

x p ктеризов но головні водоносні горизонти, поширені н території м. ьвов . ро н лізов но ключові чинники, що вплив ють н ступінь з хищеності т ур зливості підземних вод. цінено природну з хищеність т ур зливість різновікових водоносних горизонтів. 'ясов но, що н йменш з хищеними від з бруднення є води четвертинного водоносного комплексу. ещо більше з хищені й менш ур зливі води опільського і тир ського водоносних горизонтів 6 денію, що з ляг ють під косівськими глин ми. йбільше з хищені н пірні води крейдового водоносного горизонту, що розміщені під товщею четвертинних і міоценових відкл дів.

лючові слов : підземні води, з хищеність, ур зливість, з бруднення, зон ер ції.

рб нізов ні території, особливо великі міст т промислово-міські гломер ції, є потужними вогнищ ми техногенного впливу н всі скл дові природного середовищ , у тому числі й н підземні води. огляду н це особливо гостро стоїть пит ння охорони підземних вод від з бруднення.

ожливість т м сшт би техногенного з бруднення підземних вод з леж ть від 6 г тьох чинників, ключову роль серед яких відігр є їхня природн 3 хищеність (ур зливість).

ід ур зливістю підземних вод до з бруднення, з . естоп ловим (2007), розуміють комплексну 6 р'єрну функцію верхньої ч стини геологічного середовищ, як визн чен ступенем розвитку екр нув льних (н явність ш рів з низькою проникністю), ємнісних фізичних (н явність відкл дів чи фр кцій порід з високими зн ченнями пористості, дисперсності) і геохімічних (сорбція) 6 р'єрів. ей пок зник ф ктично х р ктеризує чутливість підземних вод до техногенного з бруднення. ін протилежний поняттю природної з хищеності, яку тр ктують як ступінь перекритості (ізольов ності) водоносного горизонту водонепроникними відкл д ми, які перешкодж ють проникненню з бруднюв льних речовин з поверхні землі у підземні води $[2,5]$.

ирішенню теоретичних, методичних і прикл дних проблем оцінки ур зливості (з хищеності) підземних вод присвячено зн чну кількість н укових пр ць 3 рубіжних [2, 3,7 т ін.] і вітчизняних [6 т ін.] дослідників. йгрунтовніше в кр їні проблеми оцінки з хищеності (ур зливості) підземних вод до нтропогенного з бруднення висвітлено в моногр фії . естоп лов зі спів втор ми [6]. ній розглянуто історію виникнення цього поняття, методи його оцінюв ння, основні п р метри, які використовуються для н лізу, вплив зон швидкої фільтр ції т мігр ції н ступінь ур зливості.

роблеми оцінки ур зливості підземних вод урб нізов них територій кр їни в н уковій літер турі пр ктично не висвітлені. е повною мірою стосується і міст ьвов - н йбільшого у з хідному регіоні кр їни.

(C) олошин ., 2012 
хищеність (ур зливість) підземних вод до з бруднення є в жливим чинником екологічної стійкості території міст . он зн чно з лежить від н явності і потужності сл бкофільтрув льних грунтів у зоні ер ції, глибини з ляг ння підземних вод, розчленов ності рельєфу, типу грунту т його сорбційних вл стивостей.

ериторія ьвов $є$ в меж $\mathrm{x}$ лицького гідрогеологічного р йону, олино- одільського ртезі нського 6 сейну [4].

мови з ляг ння, особливості т з кономірності поширення і формув ння підземних вод міст ьвов визн чені генезисом т умов ми з ляг ння порід різного речовинного скл ду, т кож рельєфом території. явність ос дових порід різного літологічного скл ду зумовил формув ння н території міст низки водоносних комплексів, що охоплюють стр тигр фічні підрозділи від верхньокрейдового до четвертинного віку: водоносний комплекс голоценових (суч сних), четвертинних, міоценових т верхньокрейдових відкл дів.

олоценовий водоносний комплекс включ є три водоносні горизонти: суч сних люві льних, люві льно-болотних т озерно-болотних відкл дів.

одоносний горизонт люві льних $m$ люві льно-болотних відкл дів приурочений до днищ долин річок ( олтви, руньки, убри, сіки, лехівки) т потоків ( олодновідківського, ілогірського, яснянського, окільницького, улецького, леп рівського т ін.). бл сть поширення горизонту територі льно відповід $є$ площі поширення 3 пл вного т ст ричного лювію. либин $з$ ляг ння вод колив ється від 0,5 до 1,5-3,0 м. он ер ції скл ден з торфов ними і з муленими супіск ми, суглинк ми і торф ми. оефіцієнт фільтр ції з торфов них суглинків ст новить 0,02-0,2 м/добу, торфів - 0,30,4 м/добу.

одоносний горизонт суч сних озерно-болотних відкл дів приурочений до поверхневих, з болочених к рстових форм: д вніх к рстових лійок, к рстових блюдець, улоговин тощо, поширених н ьвівському пл то т у ілогоро- льчицькій долині. одовмісними є піщ но-глинисті з торфов ні відкл ди і торфи. отужність цього водоносного горизонту незн чн і не перевищує 1,5-2,0 м. либин з ляг ння дзерк л змінюється від 0,3-0,5 до 1,0 м. ого живлення головно тмосферне.

одоносний горизонт верхньочетвертинних лесових $m$ люві льних відкл дів н лежить до н йпоширеніших н території міст . есовий водоносний горизонт поширений н всій рівнинній ч стині ьвівського пл то, лесових п $\mathrm{cm}$ х лого олісся, сл бко розчленов них ділянк $\mathrm{x}$ озточчя. одовмісними пород ми є леси, лесоподібні суглинки і супіски, іноді дрібні т пилув ті піски. либин з ляг ння рівня грунтових вод змінюється від 1,0-1,5 біля підніжжя схилів і у меж х внутрішньоп смових долин до 3,0-8,0 м і більше н вододіл х. отужність водоносного горизонту колив ється від 36 до 10 м. оефіцієнт фільтр ції порід зони ер ції змінюється від 0,5-0,05 м/добу в лес х і викопних грунт х до 1,0-5,0 м/добу у піск х.

оди люві льних відкл дів приурочені до першої н дз пл вної тер си р. олтви. одовмісними є супіски, суглинки і піски. либин 3 ляг ння вод не перевищує 1,5-3,0 м. оефіцієнти фільтр ції порід зони ер ції колив ються в меж х 0,02-3,0 м/добу.

одоносний горизонт середньо-р нньочетвертинних відкл дів поширений перев жно у північно-з хідній ч стині ділянки досліджень. схил х долин ілогірського потоку він н ближ ється безпосередньо до поверхні землі. південній т центр льній ч стин х ьвівського пл то і лесових п см х лого олісся цей горизонт підстелює верхньочетвертинний в еолово-делюві льних лес х, нерідко він $є$ першим від поверхні. одовмісні породи - піски, лесоподібні супіски т ш рув ті лесово-піщ ні п чки. ли- 
бин 3 ляг ння вод колив ється від 0,5 до 2,5 м у долині ілогірського потоку до 8-12 м н вододільних ділянк х лесових п сом.

одоносний комплекс нижньочетвертинних відкл дів охоплює дв водоносні горизонти: льодовикових т воднольодовикових відкл дів. ьодовикові відкл ди обводнені спор дично. оди тр пляються у них лише в місцях поширення піщ них т супіщ носуглинистих порід і приурочені до північно-з хідної ч стини міст ( ев ндівський виступ ьвівського пл то і верхів'я білогірського потоку). зерк ло цього типу вод є н глибині $0,5-1,5$ м.

одоносний горизонт водно-льодовикових відкл дів поширений лише в долині ілогірського потоку. одовмісними є різнозернисті піски з прош рк ми супісків і суглинків. отужність водоносного горизонту н окремих ділянк х досяг є 6-10 м. оди цього горизонту з ляг ють н глибин х від 1-2 до 3-6 м. ого живлення перев жно тмосферне. оефіцієнт фільтр ції порід зони ер ції колив ється від 0,1 до 5,0 м/добу.

одоносний горизонт нерозчленов них делюві льно-пролюві льних відкл дів поширений біля підніжжя схилів т у днищ х ярів. одовмісні породи - піш но-супіш ні т суглинисті н копичення з ул мк ми пісковиків і в пняків. либин 3 ляг ння дзерк л вод змінюється від 0,5-1,0 до 1,5-3,0 м. сильно розчленов ній ч стині ьвівського пл то і н озточчі під незн чним лесовим покривом верхнього плейстоцену іноді пр ктично з поверхні з ляг є потужн (до 100 м) товщ міоценових відкл дів. он скл ден різнозернистими піск ми з прош рк ми в пняків і пісковиків, іноді з прош рк ми бентонітових глин.

центр льній і з хідній ч стині ьвівського пл то під четвертинними відкл д ми 3 ляг є потужний (до 30-40 м) комплекс р ннього, середнього т пізнього 6 денію. ітологічно він суттєво відрізняється від міоценової товщі північно-східної ч стини міст . езпосередньо під четвертинним покривом з ляг є досить потужн (10-20 м) товщ глин косівської світи міоцену. ідкл ди косівської світи тр пляються в цьому p йоні м йже повсюди, з винятком долин потоків, де вони повністю бо ч стково розмиті. ітологічний скл д порід світи перев жно глинистий, лише н окремих ділянк х є прош рки пісковиків т пісків. оефіцієнт фільтр ції глин - менше 0,001 м/добу. они пр ктично водонепроникні. оефіцієнт фільтр ції пісковиків змінюється від 0,01 до 0,9 м/добу.

ижче косівської світи з ляг є водоносний горизонт тир ських відкл дів, приурочений до гіпсо- нгідритової товщі. іпсо- нгідрити з ляг ють з розмивом н пісковиК х т піск х опільського горизонту. либин з ляг ння змінюється в широких меж х. північно-з хідній ч стині міст ( ясн - уськ ), у пр вому борту ілогірського потоку вони виходять н поверхню бо є н глибині 3-6 м. південній т південно-з хідній ч стин х глибин 3 ляг ння гіпсів ст новить 12-15 і н віть 26 м. дебільшого гіпси з ляг ють н глибин х від 10 до 20 м.

хня потужність колив ється в широких меж х - від 1-3 до 27,6 м. ілянки з підвищеною їх потужністю (10-15 м) тяжіють перев жно до південної ч стини гіпсового м сиву. одозб г ченість цього горизонту визн чен ступенем тріщинув тості порід і колив ється в досить широких меж х. йвищ водопровідність з фіксов н в долин х потоків. т ких ділянк х коефіцієнт фільтр ції гіпсів перевищує 100 м/добу. вододіл х він колив ється від 1-4 до 10 м/добу. ісцями гіпси пр ктично водонепроникні. і водим ють н пір, зн чення якого нерідко перевищує 5-10 м.

одоносний горизонт нижньоб денських відкл дів розвинутий пр ктично н всій досліджув ній території. одовмісними є пісковики, піски т в пняки опільської світи. ьо- 
го горизонту нем лише н ділянк х н йглибшого врізу долин потоків. звич й, води цього горизонту з вдяки н пору по системі тектонічних порушень розв нт жуються у гіпсо- нгідритову товщу, іноді безпосередньо у долини потоків. оефіцієнти фільтр фії порід опільської світи змінюються від 0,2 до 92 м/добу.

одоносний горизонт верхньокрейдових відкл дів м йже всюди підстелює опис ні вище горизонти. ише н окремих ділянк х він є першим від поверхні землі. одовмісні породи - тріщинув ті мергелі м стрихтського ярусу. бводненість порід дуже різн як у пл ні, т к і з глибиною т визн чен ступенем його тріщинув тості.

йже всюди у верхній ч стині товщі простежується кор звітрюв ння мергелів. он головно предст влен мергелистою глиною, рідше щебенем мергелю з глинистим н повнюв чем. ергелисті глини м ють, з звич й, низький коефіцієнт фільтр ції, - менше 0,001 м/добу, і є водотривом, який розділяє верхньокрейдовий і нижньоб денський водоносні горизонти. отужність мергелястих глин змінюється в широких меж $\mathrm{x}-$ від 0,51,0 до 10,0 м. йменш товщин ш ру глин з реєстров н в долин х річок і потоків. окремих ділянк х долини р. олтви ії зовсім нем . н чн потужність глин сприяє н пірному х р ктеру цього водоносного горизонту. н чення н пору змінюється від 0,0 до 10,0-12,0 м. оефіцієнт фільтр ції мергелів з лежно від ступеня тріщинув тості колив ється в меж х $0,5-33$ м/добу.

6 г тьох ділянк х верхньої ч стини долини р. олтви (центр льн ч стин міст ) мергелі виходять безпосередньо н поверхню чи вкриті незн чним з потужністю пл щем (3-6 м) техногенних відкл дів. отужність мергелястих глин н схил х долини місцями досяг є 3-5 м.

меж х сильно розчленов них ьвівсько- ібрського горбогір'я т озточчя міоценовий водоносний комплекс пр ктично повністю здренов ний. ише н окремих ділянК х у нижній ч стині товщі фіксов но м лопотужний водоносний горизонт, сформов в ний н водотривких мергелистих глин х верхньої крейди.

цінку ур женості (з хищеності) першого від поверхні водоносного горизонту від поверхневого з бруднення виконув ли з використ нням т ких чинників, як потужність зони ер ції, коефіцієнт фільтр ції порід, що ії формують, т ступінь розчленов ності рельєфу.

н ліз чинників, що визн ч ють природну з хищеність підземних вод ьвов свідчить про те, що вони м ють різний ступінь. оди першого від поверхні водоносного горизонту люві льно-болотних відкл дів, верхньочетвертинних лесів з глибиною з ляг ння дзерк л вод до 5 м, р нньо-середньочетвертинних відкл дів, що з ляг ють близько від поверхні, т кож відкл дів міоценового комплексу розчленов ної ч стини ьвівського пл то і озточчя з потужністю зони ер ції до 20 м н леж ть до к тегорії нез хищених, з високим ступенем ур зливості до нтропогенного з бруднення.

рунтові води верхньо-середньочетвертинних лесових відкл дів, що вміщують викопні грунти і з ляг ють н глибин х пон д 10 м, н леж ть до недост тньо з хищених - середнього ступеня ур зливості. р ктерною особливістю лесових товщ $є$ їхня яскp во вир жен нізотропія фільтр ційних вл стивостей. они м ють добру водопроникність у вертик льному і низьку - в горизонт льному н прям х. рім того, у лесовогрунтових товщ $\mathrm{x}$ тр пляється не менше чотирьох генер цій псевдоморфоз по полігон льно-жильних льод $\mathrm{x}$, н повнюв ч яких м є підвищені фільтр ційні п р метри і які р зом з поверхневими блюдцеподібними з п дин ми формують зони швидкої фільтр ції. меж х т ких зон зн чно нижч 3 г льн з хищеність і вищ ур зливість підземних вод. 


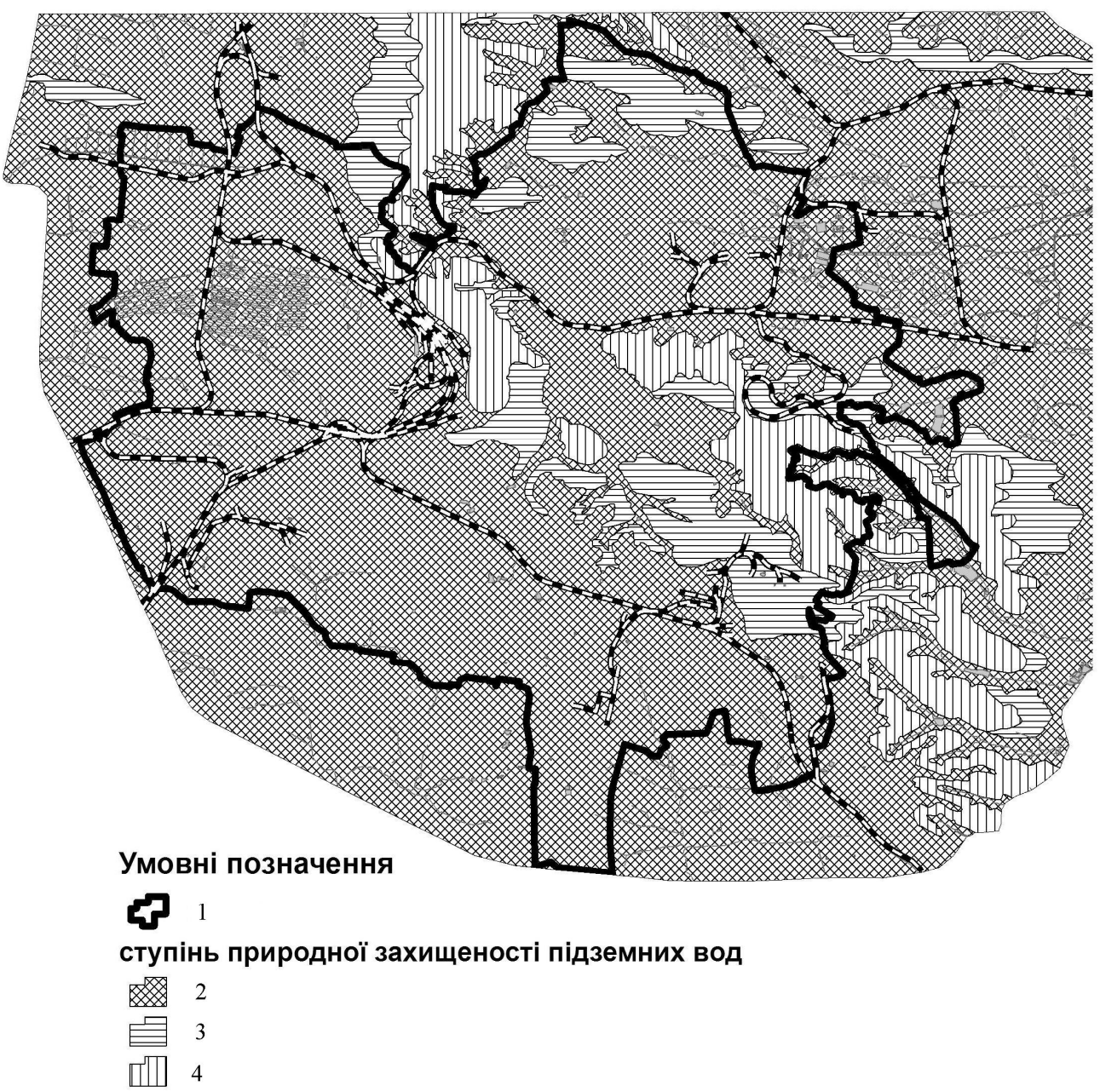

ис. 1. ртосхем природної з хищеності першого від поверхні водоносного горизонту н території м. ьвів.

ідземні води в міоценових відкл д х з потужністю зони ер ції до 40 м т верхньокрейдових мергелях, що з ляг ють під незн чною товщею суч сних техногенних т четвертинних н копичень, т кож н леж ть до недост тньо з хищених. о цієї к тегорії н лежить і нижньоб денський водоносний горизонт, поширений у меж х сильно розчленов ного ьвівського пл то т озточчя, перерекритий зверху 3-6 м п чкою лесів, який з ляг є н глибині пон д 40 м.

пірні води середнього і нижнього б денію т верхньої крейди, які з ляг ють під косівськими глин ми, м ють різний ступінь з хищеності т ур зливості. ділянк х підвищеної з к рстов ності гіпсів і незн чної потужності мергелистих глин вони недост тньо з хищені. місцях, де гіпсо нгідритів нем , їх можн з числити до к тегорії з хищених і н йменш ур зливих до з бруднення. 
ртосхем ступеня з хищеності першого від поверхні водоносного горизонту пок 3 н н рисунку 1 .

к б чимо, підземні води водоносних горизонтів різних генетичних типів порід i порід різного віку н леж ть головно до к тегорії нез хищених т недост тньо з хищених. ише незн чні з площею території з числено до помірно з хищених. они приурочені головно до сильно розчленов них ділянок з великою потужністю (пон д 40 м) зони ер ції т вкритих з поверхні лес ми.

езв ж ючи н якісну оцінку отрим них д них, вони д ють змогу вирішув ти широке коло пл нув льних з вд нь, у тім числі й розміщення екологічно небезпечних об'єктів.

ількісн оцінк 3 хищеності т ур женості підземних вод ьвов до з бруднення потребує дет льного вивчення фільтр ційних т сорбційних вл стивостей порід зони ер ції.

1. олошин . нтропогенні зміни вод підземної гідросфери центр льної ч стини ьвов // icник ьвів. ун-ту. ерія геогр. 2003. ип. $29-$. 145-150.

2. ольдберг . . риродные и техногенные ф кторы 3 щищенности грунтовых вод // юл. , 1983. № 2. - . 103-110.

3. екцер . . егион льн я оценк уязвимости пресных подземных вод: методологические спекты и пр ктическое применение / . . екцер, . . римов , . ужуоли, . уччи // одные ресурсы, 2004, том 31, № 6. - . 645-650.

4. егенд до гідрогеологічної к рти комплекту держ вної геологічної к рти кр їни м сшт бу 1: 200000. олино- одільськ серія. ояснюв льн з писк . . . леський, . . нін . - . : ерж. геол. служб , 2006. - 28 с.

5. етодические рекоменд ции по гидрогеологическим исследов ниям и прогноз м для контроля з охр ной подземных вод. - ., 1987. - 86 с.

6. ecmon лов . . ценк з щищен- ности и уязвимости подземных вод с учетом зон быстрой мигр ции / . . естоп лов, . . огусл вский, . . ублясь. - иев, 2007. - 120 с.

7. Margat J. 1968. Vulnerabilite des nappes d'eau souterraine a la polution (Vulnerability of groundwater to pollution).BRGM ublication 68 SGL 198 HYD. Orleans.

m ття: н дійшл до редколегії 17.10.2011 прийнят до друку 20.12.2011

\section{THE ESTIMATION OF NATURAL PROTECTABILITY AND VULNERABILITY OF GROUND WATER TO ANTHROPOGENIC POLLUTION WITHIN TERRITORY OF LVIV}

\section{P. Voloshyn}

Ivan Franko National University of Lviv, . Doroshenko St., 41, UA - 79000 Lviv, Ukraine

The main groundwater horizons of Lviv area are characterized. The key factors of their protectability and vulnerability are analyzed. Natural pro-tectability of of different age aquiferous horizons was estimated. Least protected from pollution are waters of Quaternary aquiferous horizon. Slightly better protected are waters of Opillia and Tyras aquiferous horizons of Badenian located at the bottom under Kosiv clay layers. Most protected are urgent waters of Cretaceous horizon placed under Quarternary layer and Miocene sediments.

Key words: ground waters, protectiveness, vulnerability, pollution, aeration zones. 


\section{• олошин}

ввовский н цион льный университет имени в н р нко, ул. . орошенко, 41, г. ввов, 79000, кр ин

x p ктеризов но основные водоносные горизонты, $\mathrm{p}$ спростр ненные н территории г. ьвов. ро н лизиров ны гл вные ф кторы, влияющие н степень 3 щищенности и уязвимости подземных вод. ценено природную з щищенность р зновозр стных водоносных горизонтов. ст новлено, что н именее 3 щищены от 3 грязнения подземные воды четвертичного водоносного комплекс . олее з щищенными и менее уязвимыми являются воды опольского и тир сского водоносных горизонтов б дения, которые з лег ют под косовскими глин ми. н иболее $з$ щищенным относятся н порные воды верхнемеловых отложений, н ходящихся под четвертичной и миоценовой толщей.

лючевые слов : подземные воды, з щищенность, уязвимость, з грязнение, зон эр ции. 